Article

\title{
Unveiling the Temperature Influence on the Sorptive Behaviour of ZIF-8 Composite Materials Impregnated with $\left[\mathrm{C}_{\mathrm{n}} \mathrm{MIM}\right]\left[\mathrm{B}(\mathrm{CN})_{4}\right]$ Ionic Liquids
}

\author{
Tiago J. Ferreira (D), Laura M. Esteves, José M. S. S. Esperança *(D) and Isabel A. A. C. Esteves *D
}

Citation: Ferreira, T.J.; Esteves, L.M.; Esperança, J.M.S.S.; Esteves, I.A.A.C. Unveiling the Temperature Influence on the Sorptive Behaviour of ZIF-8 Composite Materials Impregnated with $\left[\mathrm{C}_{\mathrm{n}} \mathrm{MIM}\right]\left[\mathrm{B}(\mathrm{CN})_{4}\right]$ Ionic Liquids. Processes 2022, 10, 247. https:/ / doi.org/10.3390/pr10020247

Academic Editor: Giancarlo Cravotto

Received: 1 December 2021

Accepted: 23 January 2022

Published: 27 January 2022

Publisher's Note: MDPI stays neutral with regard to jurisdictional claims in published maps and institutional affiliations.

Copyright: (C) 2022 by the authors. Licensee MDPI, Basel, Switzerland. This article is an open access article distributed under the terms and conditions of the Creative Commons Attribution (CC BY) license (https:// creativecommons.org/licenses/by/ $4.0 /)$
LAQV / REQUIMTE, Departamento de Química, Faculdade de Ciências e Tecnologia, Universidade NOVA de Lisboa, 2829-516 Almada, Portugal; tjo.ferreira@campus.fct.unl.pt (T.J.F.); lm.esteves@fct.unl.pt (L.M.E.)

* Correspondence: jmesp@fct.unl.pt (J.M.S.S.E.); i.esteves@fct.unl.pt (I.A.A.C.E.)

\begin{abstract}
Composite sorbent materials (IL@MOF) with a metal-organic framework (MOF) ZIF-8 and $\left[\mathrm{B}(\mathrm{CN})_{4}\right]^{-}$-based ionic liquids (ILs) were produced for the first time. Characterization results indicate the successful IL impregnation and conservation of the ZIF-8 crystalline structure and morphology. The data collected from the nitrogen $\left(\mathrm{N}_{2}\right)$ physisorption at $77 \mathrm{~K}$ suggest that these IL@ZIF-8 materials are nonporous as their textural properties, such as BET specific surface area and total pore volume, are negligible. However, $\mathrm{CO}_{2}, \mathrm{CH}_{4}$, and $\mathrm{N}_{2}$ adsorption/desorption measurements in the IL@ZIF8 composites at 303 and $273 \mathrm{~K}$ contradict the $\mathrm{N}_{2}$ data at $77 \mathrm{~K}$, given that the obtained isotherms are Type I, typical of (micro)porous materials. Their gas adsorption capacity and ultramicroporous volume are in the same order of magnitude as the pristine microporous ZIF-8. The case study $\left[\mathrm{C}_{6} \mathrm{MIM}\right]\left[\mathrm{B}(\mathrm{CN})_{4}\right]$ IL revealed a high affinity to both $\mathrm{CO}_{2}$ and $\mathrm{CH}_{4}$. This compromised the selectivity performance of its respective composite when compared with pristine ZIF-8. This work highlights the importance of accurate experimental gas adsorption/desorption equilibrium measurements to characterize the adsorption uptake and the porous nature of adsorbent materials.
\end{abstract}

Keywords: $\mathrm{CO}_{2}$ separation; gas adsorption; ionic liquids (ILs); metal-organic frameworks (MOFs); composite porous materials

\section{Introduction}

Developing new sorbent materials for carbon dioxide $\left(\mathrm{CO}_{2}\right)$ capture/separation is vital for responding to global warming and its impacts [1,2]. Technologies like gas absorption, gas adsorption, membrane permeation, and chemical looping, among others, have been proposed for $\mathrm{CO}_{2}$ capture [3,4]. Different classes of materials have been considered for this purpose, such as ionic liquids (ILs) [5], metal-organic frameworks (MOFs) [6], covalentorganic frameworks (COFs) [7], or hybrid ultramicroporous materials (HUMs) [8]. In the last decade, the production of MOF-based composite materials for gas adsorption has been proposed [9]. Specifically, the incorporation of ILs into the structure of a MOF, named IL@MOF composite materials, has been studied [10]. In these studies, it is frequently assessed the $\mathrm{CO}_{2}$ separation from gaseous mixtures of topical interest that include methane $\left(\mathrm{CH}_{4}\right)$ [11] or nitrogen $\left(\mathrm{N}_{2}\right)$ [12] in their composition. Sorbent material properties like gas sorption capacity and selectivity performance are crucial to understanding the IL impact on the gaseous mixture separation compared to the pristine MOF. Ultimately, the desire is that IL impregnation creates a synergistic effect that improves both the $\mathrm{CO}_{2}$ uptake and selectivity of the composite material [10].

In a previous study by our group [13], different ILs were incorporated with the same molar loading into the structure of the MOF ZIF-8 to study their cation and anion effects and how ILs impact gas adsorption and selectivity of the material. All but one IL in their bulk phase absorb $\mathrm{CO}_{2}$ by physisorption, while $\left[\mathrm{C}_{2} \mathrm{MIM}\right][\mathrm{Ac}]$ absorbs the gas by chemisorption. Two cyano-based ILs, namely $\left[\mathrm{C}_{6} \mathrm{MIM}\right]\left[\mathrm{N}(\mathrm{CN})_{2}\right]$ and $\left[\mathrm{C}_{6} \mathrm{MIM}\right]\left[\mathrm{C}(\mathrm{CN})_{3}\right]$, 
were used to produce IL@ZIF-8 composites, along with the fluorinated $\left[\mathrm{C}_{6} \mathrm{MIM}\right]\left[\mathrm{NTf}_{2}\right]$. High $\mathrm{CO}_{2}$ solubility has been reported for fluorinated ILs [14], although the cyano-based composites showed superior $\mathrm{CO}_{2}$ uptake between 0-16 bar than $\left[\mathrm{C}_{6} \mathrm{MIM}\right]\left[\mathrm{NTf}_{2}\right] @ Z I F-8$.

Additionally, Carvalho et al. [15] compared the $\mathrm{CO}_{2}$ solubility of functionalized ILs with a generic n-alkane called eicosane. It was concluded that, in molality units, only cyanobased ILs containing the anion $\left[\mathrm{B}(\mathrm{CN})_{4}\right]^{-}$showed superior $\mathrm{CO}_{2}$ solubility than eicosane. This means that, compared to a common and cheap n-alkane, only $\left[\mathrm{B}(\mathrm{CN})_{4}\right]^{-}$-based ILs showed superior $\mathrm{CO}_{2}$ solubility. Another study by Zakrzewska and Nunes da Ponte [16] determined $\mathrm{CO}_{2}$ solubilities at $303.15 \mathrm{~K}$ for $\left[\mathrm{C}_{2} \mathrm{MIM}\right]\left[\mathrm{B}(\mathrm{CN})_{4}\right]$ and $\left[\mathrm{C}_{6} \mathrm{MIM}\right]\left[\mathrm{B}(\mathrm{CN})_{4}\right]$ between 0-190 bar. These solubilities were found to be comparable or even slightly superior to the ones found for $\left[\mathrm{NTf}_{2}\right]^{-}$-based ILs. This indicates that $\left[\mathrm{B}(\mathrm{CN})_{4}\right]^{-}$-based ILs have the potential to surpass the $\left[\mathrm{NTf}_{2}\right]^{-}$-based ILs, which are commonly referred to in the literature as the best ILs for $\mathrm{CO}_{2}$ capture [17].

In this work, MOF ZIF-8 was impregnated for the first time with $\left[\mathrm{C}_{\mathrm{n}} \mathrm{MIM}\right]\left[\mathrm{B}(\mathrm{CN})_{4}\right] \mathrm{ILs}$, considering their proven high $\mathrm{CO}_{2}$ solubility, and the derived composites were fully studied. Different characterization techniques were employed to confirm the IL impregnation and to determine its impact on the crystalline structure, morphology, and textural properties of the produced composites, and ultimately on their sorption performance (with both cation and loading effects being studied). Complementary adsorption/desorption measurements of $\mathrm{CO}_{2}, \mathrm{CH}_{4}$, and $\mathrm{N}_{2}$ at $303 \mathrm{~K}$ and in a pressure range of 0-16 bar were obtained for the composites. The adsorption behavior of $\left[\mathrm{C}_{n} \mathrm{MIM}\right]\left[\mathrm{B}(\mathrm{CN})_{4}\right]$-based materials upon the adsorbates and temperatures studied should serve as a warning to researchers developing new composite materials for gas sorption applications.

\section{Materials and Methods}

\subsection{Materials}

The MOFs ZIF-8 (Basolite ${ }^{\circledR}$ Z1200) and MIL-53(Al) (Basolite ${ }^{\circledR}$ A100) were purchased from Sigma-Aldrich. The ILs 1-ethyl-3-methylimidazolium tetracyanoborate $\left(\left[\mathrm{C}_{2} \mathrm{MIM}\right]\left[\mathrm{B}(\mathrm{CN})_{4}\right]\right.$, $\geq 99.5 \%)$ and 1-hexyl-3-methylimidazolium tetracyanoborate $\left(\left[\mathrm{C}_{6} \mathrm{MIM}\right]\left[\mathrm{B}(\mathrm{CN})_{4}\right], \geq 98.0 \%\right)$ were acquired from Merck. The IL 1-hexyl-3-methylimidazolium tetrafluoroborate $\left(\left[\mathrm{C}_{6} \mathrm{MIM}\right]\left[\mathrm{BF}_{4}\right]\right.$, 99.0\%) was purchased from IoLiTec GmbH. Acetone (99.8\%, Carlo Erba) was used for IL dissolution before MOF impregnation. Potassium bromide (KBr; Panreac) was used to prepare the FT-IR tablets. Finally, the gases used in the adsorption/desorption equilibrium measurements, namely, $\mathrm{N}_{2}(>99.998 \%), \mathrm{CH}_{4}(>99.95 \%), \mathrm{CO}_{2}(99.998 \%)$, and $\mathrm{He}(\geq 99.999 \%)$, were supplied by Air Liquide.

\subsection{Samples Preparation}

The protocol developed previously for IL@MOF materials production can be found elsewhere [13]. Briefly, $0.45 \mathrm{mmol}$ of IL, vacuumed at $0.1 \mathrm{~Pa}$ and $323 \mathrm{~K}$ for at least $24 \mathrm{~h}$, was weighed and dissolved in $10 \mathrm{~mL}$ of acetone. This IL quantity was applied in all but one composite produced for this work (generically named herein as IL@ZIF-8 (low)). For the composite named $\left[\mathrm{C}_{6} \mathrm{MIM}\right]\left[\mathrm{B}(\mathrm{CN})_{4}\right] @ \mathrm{ZIF}-8$ (high), an IL amount of $1.10 \mathrm{mmol}$ was used instead. The IL solution was stirred at room temperature for $15 \mathrm{~min}$. Then, $1 \mathrm{~g}$ of ZIF-8 (degassed for $4 \mathrm{~h}$ at $373 \mathrm{~K}$ ) was weighed, and the IL solution was added to the MOF vial. The mixture was then capped and stirred overnight. Afterwards, the cap was removed and to promote acetone evaporation, samples were dried for $4 \mathrm{~h}$ at room temperature and then at $338 \mathrm{~K}$. A final degassing step at $373 \mathrm{~K}$ was performed for $4 \mathrm{~h}$ to remove any traces of volatile components.

\subsection{Samples Characterization}

\subsubsection{Fourier Transform Infrared (FT-IR) Spectroscopy}

Infrared spectra of the materials were obtained at room temperature conditions, between 4000 and $450 \mathrm{~cm}^{-1}$ (spectral resolution of $4 \mathrm{~cm}^{-1}$ ), with a FT-IR Spectrometer Spectrum Two model (PerkinElmer). For neat ILs, an Attenuated Total Reflectance (ATR) 
modulus was used. For solid samples (ZIF-8 and IL@ZIF-8 composites), spectra were acquired with a Transmittance modulus. In this case, $\mathrm{KBr}$ tablets were produced containing some milligrams of solid sample.

\subsubsection{Powder X-ray Diffraction (PXRD)}

The PXRD diffractograms of the materials were obtained using a MiniFlex II diffractometer (Rigaku), with an X-ray generator of $30 \mathrm{kV}$ voltage and $15 \mathrm{~mA}$ current. A copper radiation source was used (radiation wavelength of $1.5406 \AA$ ), and analyses were run between $2 \theta$ values of $2^{\circ}$ and $50^{\circ}\left(0.02^{\circ}\right.$ step).

\subsubsection{Scanning Electron Microscopy (SEM)}

SEM micrographs of the materials were obtained with a Zeiss Auriga CrossBeam Workstation SEM-FIB equipment ( $\times 50 \mathrm{k}$ magnification). To obtain high-quality SEM images, the materials were covered with a layer of gold prior to the analysis.

\subsubsection{Textural Properties of ZIF-8 and IL@ZIF-8 Composites}

To determine the textural properties of the produced composites, $\mathrm{N}_{2}$ adsorption/ desorption isotherms of the materials were obtained at $77 \mathrm{~K}$ with a static volumetric apparatus ASAP 2010 (Accelerated Surface Area and Porosimetry System, Micromeritics). Before each measurement, the material was degassed under vacuum for $4 \mathrm{~h}$ at $373 \mathrm{~K}$. Different textural properties of the materials, including total pore volume $\left(V_{\mathrm{p}}\right)$ and specific BET surface area $\left(A_{\mathrm{BET}}\right)$, were determined using the BET volumetric method assuming multilayer formation on the solid surface [18,19]. The Dubinin-Radushkevich (D-R) equation [18] was applied to the $\mathrm{CO}_{2}$ adsorption/desorption data at $273 \mathrm{~K}$ (considering points between 0-1 bar) to determine the volume of narrow micropores/ultramicropores $\left(V_{\mathrm{o}}\right)$, which are pores with a size below $7 \AA$ [19-21].

\subsection{Gas Adsorption/Desorption Equilibrium Measurements}

Adsorption/desorption equilibrium isotherms of $\mathrm{CO}_{2}, \mathrm{CH}_{4}$, and $\mathrm{N}_{2}$ were experimentally measured using a fully established standard static gravimetric method, at $303 \mathrm{~K}$ and in a pressure range of $0-16$ bar $[13,22]$. For the same pressure range, $\mathrm{CO}_{2}$ isotherms were also obtained at $273 \mathrm{~K}$ for both ZIF-8 and the composite $\left[\mathrm{C}_{6} \mathrm{MIM}\right]\left[\mathrm{B}(\mathrm{CN})_{4}\right] @ Z \mathrm{ZIF}-8$ (low).

The main feature of this gravimetric unit is a high accuracy ISOSORP 2000 magneticsuspension balance (Rubotherm $\mathrm{GmbH}$ ). About $0.3-0.4 \mathrm{~g}$ of the material of interest was used for the measurements. Despite the external degassing of the samples, an in situ degassing was also performed under vacuum at $373 \mathrm{~K}$ for $4 \mathrm{~h}$ to ensure that the materials were free from moisture or other sorbed impurities. Finally, the temperature was allowed to stabilize to the desired value ( 273 or $303 \mathrm{~K}$ ) for the measurements to start. In this work, replicate measurements were done to check data reproducibility. Further details concerning the gravimetric apparatus and methodology employed in the measurements can be found elsewhere [13,22-24].

It should be noted that "adsorption" is the prevalent phenomenon in the produced composites, as the quantity of MOF used is much higher than the IL mass itself. This term is used interchangeably herein with the technically correct term "sorption", which encompasses both gas adsorption and absorption phenomena.

The adsorbed amount of a gas can be expressed in different quantities (net, excess, or total). For a gravimetric experiment, and using mole of adsorbed gas per unit mass of adsorbent, the adsorbed amount can be expressed using a net adsorption quantity [25]:

$$
q_{\mathrm{net}}=\frac{m-m_{\mathrm{s}}-m_{\mathrm{h}}+V_{\mathrm{h}} \rho_{\mathrm{g}}}{m_{\mathrm{s}} M_{\mathrm{w}}},
$$

where $m$ is the registered weighed mass, $m_{\mathrm{S}}$ is the mass of (degassed) adsorbent material, $m_{\mathrm{h}}$ and $V_{\mathrm{h}}$ are the total mass and volume of all the physical parts of the sample holder contributing to buoyancy effects, respectively. Also, $\rho_{\mathrm{g}}$ is the density of the gas at the 
equilibrium pressure and temperature, and $M_{\mathrm{W}}$ is the molecular weight of the adsorbed gas. Reporting in net quantity avoids drawbacks regarding using probe molecules to determine the reference state. Nevertheless, most adsorption studies report total adsorption quantity $\left(q_{\mathrm{t}}\right)$ data. For this purpose, our group usually considers the total pore volume of the material as an approximation to the volume of the adsorbed phase, which cannot be experimentally determined

$$
q_{\mathrm{t}}=q_{\mathrm{exc}}+V_{\mathrm{p}} \rho_{\mathrm{g}}
$$

where $V_{\mathrm{p}}$ is the total pore volume of the material [22]. However, for this work, it was assumed to use the excess adsorption quantity $\left(q_{\mathrm{exc}}\right)$

$$
q_{\mathrm{exc}}=q_{\mathrm{net}}+\frac{\rho_{\mathrm{g}}}{\rho_{\mathrm{s}}},
$$

where $\rho_{\mathrm{s}}$ is the solid matrix density of the material. This density was determined by helium (He) pycnometry.

Isotherms were fitted using the Sips adsorption isotherm model [18]

$$
q(P)=\frac{q_{\mathrm{s}}(b P)^{1 / n}}{1+(b P)^{1 / n}}
$$

in which $q_{\mathrm{s}}$ is the saturation adsorbed quantity, $b$ is an affinity constant, and $n$ is the system heterogeneity constant.

With these fittings, ideal $\mathrm{CO}_{2} / \mathrm{CH}_{4}$ and $\mathrm{CO}_{2} / \mathrm{N}_{2}$ selectivities were determined by

$$
\begin{aligned}
S_{\mathrm{CO}_{2} / \mathrm{CH}_{4}} & =\frac{q_{\mathrm{exc} \mathrm{CO}_{2}}}{q_{\mathrm{exc} \mathrm{CH}_{4}}} \\
S_{\mathrm{CO}_{2} / \mathrm{N}_{2}} & =\frac{q_{\mathrm{exc} \mathrm{CO}}}{q_{\mathrm{exc}}}
\end{aligned}
$$

considering an equimolar composition, as well as biogas (40:60 vol. $\left.\% \mathrm{CO}_{2} / \mathrm{CH}_{4}\right)$ [26] and flue gas (15:85 vol. $\% \mathrm{CO}_{2} / \mathrm{N}_{2}$ ) [27] compositions.

\section{Results and Discussion}

\subsection{Fourier Transform Infrared (FT-IR) Spectroscopy}

Infrared spectroscopy was used to confirm the impregnation of $\left[\mathrm{C}_{6} \mathrm{MIM}\right]\left[\mathrm{B}(\mathrm{CN})_{4}\right]$ into the structure of ZIF-8. Spectra of the neat IL, MOF, and IL@MOF composite were obtained, as shown in Figure 1. A weak IL-related band can be observed in the $\left[\mathrm{C}_{6} \mathrm{MIM}\right]\left[\mathrm{B}(\mathrm{CN})_{4}\right] @ Z$ ZIF8 (low) spectrum at about $2223 \mathrm{~cm}^{-1}$ (see graph inset), which is related to the $\mathrm{C} \equiv \mathrm{N}$ bond found in the IL anion [28]. This confirms the success of the IL impregnation method. 


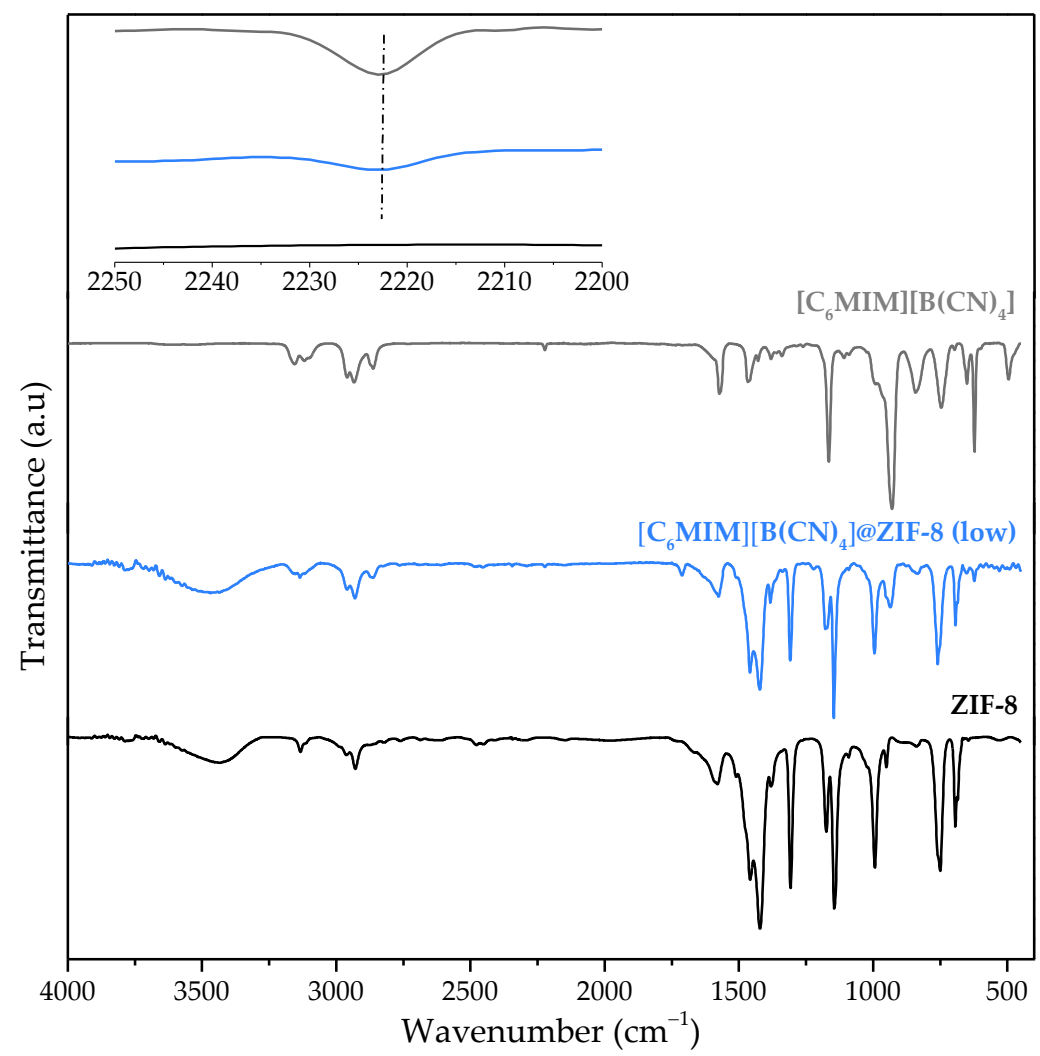

Figure 1. Infrared spectra of neat $\left[\mathrm{C}_{6} \mathrm{MIM}\right]\left[\mathrm{B}(\mathrm{CN})_{4}\right],\left[\mathrm{C}_{6} \mathrm{MIM}\right]\left[\mathrm{B}(\mathrm{CN})_{4}\right] @ Z I F-8$ (low) and pristine ZIF-8 (the inset details the spectra between 2250 and $2200 \mathrm{~cm}^{-1}$ ).

\subsection{Powder X-ray Diffraction (PXRD)}

The PXRD diffractograms of ZIF-8 and $\left[\mathrm{C}_{6} \mathrm{MIM}\right]\left[\mathrm{B}(\mathrm{CN})_{4}\right] @ \mathrm{ZIF}-8$ (low), shown in Figure 2, reveal that all the pristine MOF peaks were well-preserved, as they can be found in the composite diffractogram. This means that the IL impregnation does not compromise the MOF structure and that the produced IL@ZIF-8 material is also crystalline. The composites produced in our previous study [13] were also crystalline materials.

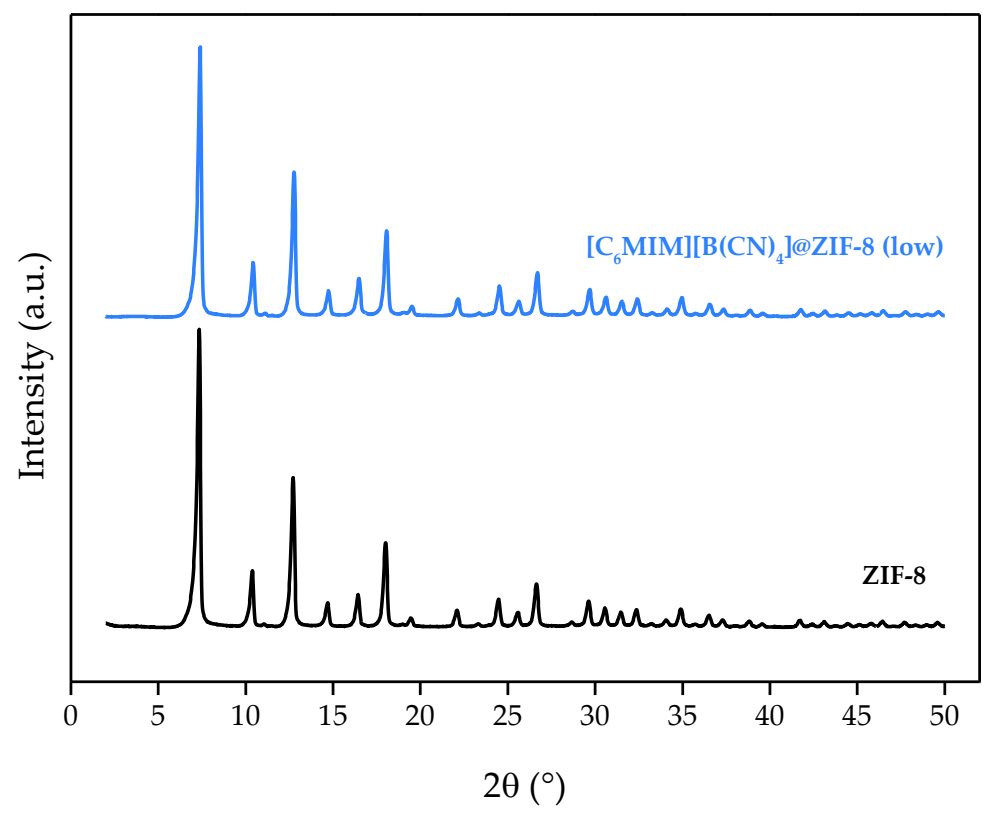

Figure 2. PXRD diffractograms of $\left[\mathrm{C}_{6} \mathrm{MIM}\right]\left[\mathrm{B}(\mathrm{CN})_{4}\right] @ \mathrm{ZIF}-8$ (low) and pristine ZIF-8. 


\subsection{Scanning Electron Microscopy (SEM)}

SEM images were obtained to confirm that the IL impregnation did not significantly affect the morphology of the MOF. As observed in Figure 3, both ZIF-8 and $\left[\mathrm{C}_{6} \mathrm{MIM}\right]\left[\mathrm{B}(\mathrm{CN})_{4}\right] @ \mathrm{ZIF}-$ 8 (low) show similar surface morphologies. It appears that the composite particles are slightly rounder than the ZIF-8 ones [13]. This is due to the presence of the IL in the structure along with the IL impregnation method itself, which uses high rotation speeds. This fact generates particles collisions that can round their edges. The composite SEM image shows that no excess IL is outside the MOF structure, although there will be a loading where the IL entirely blocks the MOF pores, and the textural properties will have negligible values [11].

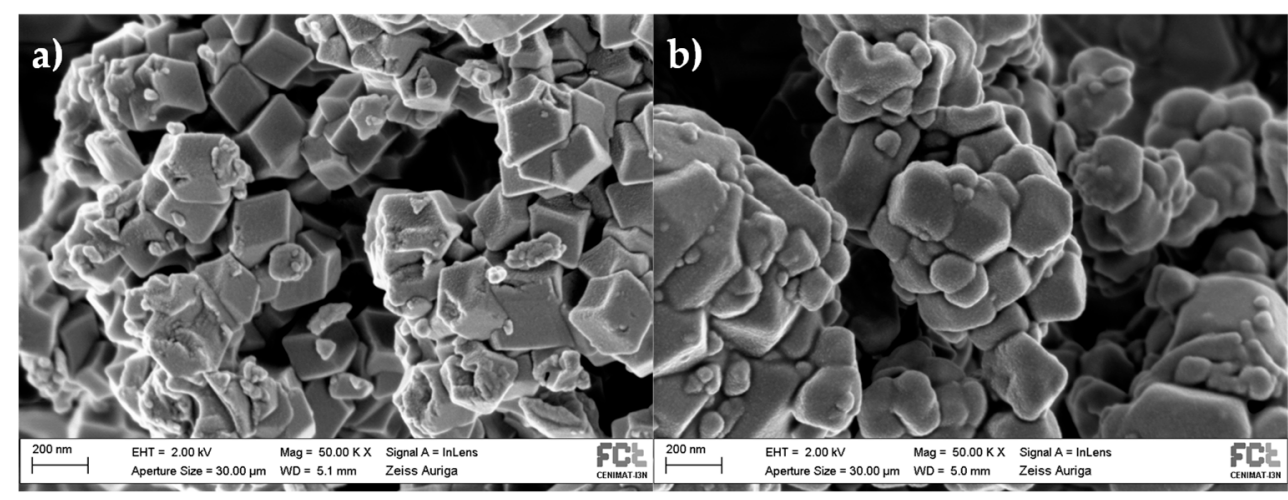

Figure 3. SEM micrographs (×50k magnification) of: (a) ZIF-8; and (b) $\left[\mathrm{C}_{6} \mathrm{MIM}\right]\left[\mathrm{B}(\mathrm{CN})_{4}\right] @ Z \mathrm{ZIF}-$ 8 (low).

\subsection{Textural Properties of ZIF-8 and IL@ZIF-8 Composites}

Up until this point, all the characterization results for $\left[\mathrm{C}_{6} \mathrm{MIM}\right]\left[\mathrm{B}(\mathrm{CN})_{4}\right] @ \mathrm{ZIF}-8$ (low) are similar to the other composites previously reported with the same IL molar loading [13]. However, the $\mathrm{N}_{2}$ adsorption/desorption isotherm at $77 \mathrm{~K}$ for this material was unexpected. As observed in Figure 4, a Type II isotherm was obtained for this composite (according to IUPAC classification [19]). This result suggests that $\left[\mathrm{C}_{6} \mathrm{MIM}\right]\left[\mathrm{B}(\mathrm{CN})_{4}\right] @ \mathrm{ZIF}-8$ (low) is a nonporous material as the intrusion of $\mathrm{N}_{2}$ at $77 \mathrm{~K}$ is very low. It should be noted that Type II isotherms are also typical of macroporous materials, but this is not the case as the $\mathrm{N}_{2}$ adsorbed amount is very low. This explains the very low total pore volume (obtained at a relative pressure of 0.95) and BET specific surface area of this composite, shown in Table 1. By contrast, pristine ZIF-8 presented a Type I isotherm, typical of microporous materials. It should be noted that, in our previous study [13], IL@ZIF-8 composites showed Type I isotherms for $\mathrm{N}_{2}$ at $77 \mathrm{~K}$ and, consequently, significant textural properties for gas sorption applications.

A different sample from this batch was used for a reproducibility assay to exclude possible poor IL dispersion during the preparation of the composite material. As observed in Figure 4 and Table 1, it also showed very low $\mathrm{N}_{2}$ adsorption, which translates into very poor textural properties for a potential adsorbent for gas adsorption applications. No hysteresis was found, which indicates the materials are completely reversible regarding $\mathrm{N}_{2}$ adsorption at $77 \mathrm{~K}$.

The composite $\left[\mathrm{C}_{6} \mathrm{MIM}\right]\left[\mathrm{BF}_{4}\right] @ \mathrm{ZIF}-8$ (low) was then produced, given that it contains the similar $\left[\mathrm{BF}_{4}\right]^{-}$anion. It presented a Type I isotherm like that of ZIF-8 and significant textural properties as observed in Table 1. This seems to indicate that whatever phenomenon is happening at $77 \mathrm{~K}$ with $\mathrm{N}_{2}$, it is associated with the $\left[\mathrm{B}(\mathrm{CN})_{4}\right]^{-}$anion of the IL. 


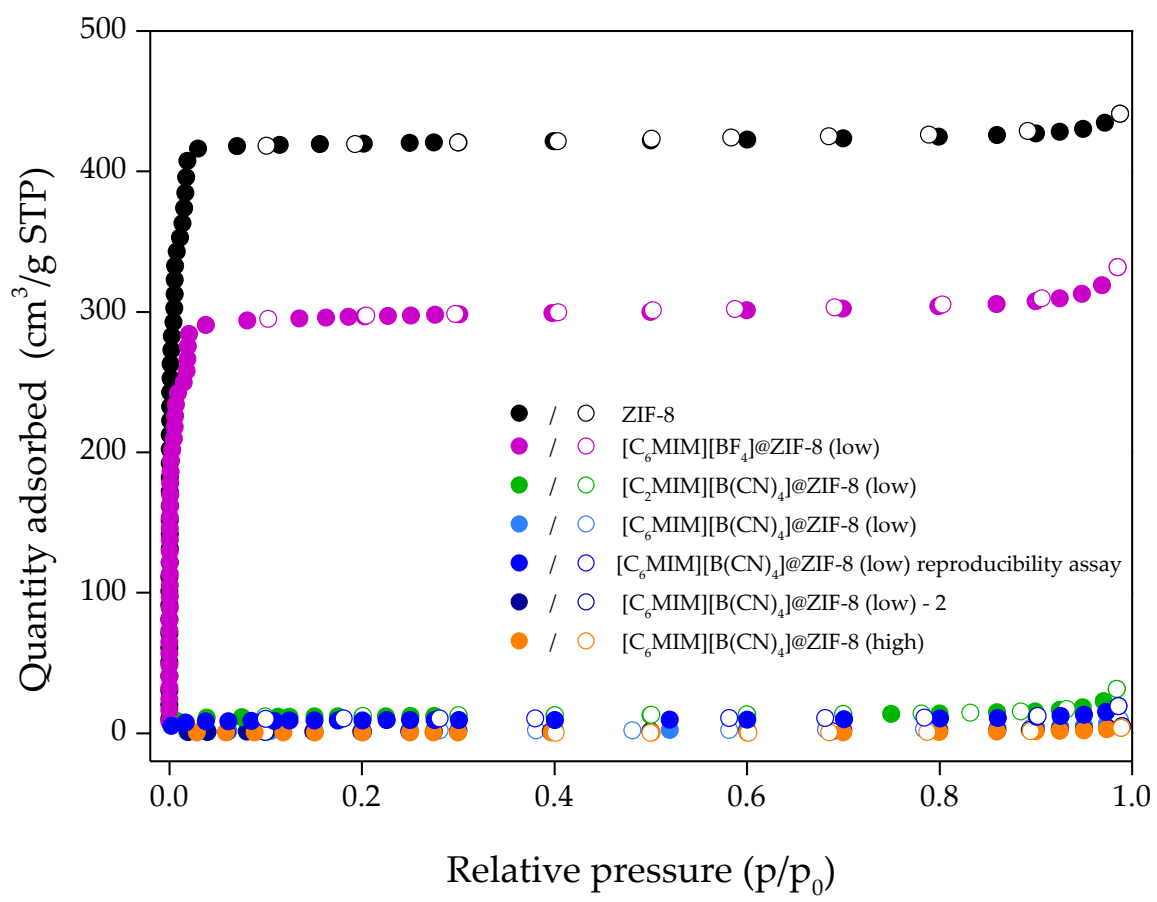

Figure $4 . \mathrm{N}_{2}$ adsorption/desorption equilibrium isotherms at $77 \mathrm{~K}$ of ZIF-8, $\left[\mathrm{C}_{6} \mathrm{MIM}\right][\mathrm{BF} 4]$ @ZIF-8 (low) and different $\left[\mathrm{C}_{\mathrm{n}} \mathrm{MIM}\right]\left[\mathrm{B}(\mathrm{CN})_{4}\right] @ Z \mathrm{ZIF}-8$ composites. Closed and open symbols denote the adsorption and desorption data, respectively.

Table 1. Total pore volume $\left(V_{\mathrm{p}}\right)$, BET specific surface area $\left(A_{\mathrm{BET}}\right)$, solid matrix density $\left(\rho_{\mathrm{s}}\right)$, and IL mass loading obtained for ZIF-8 and the various IL@ZIF-8 composites. Both $V_{\mathrm{p}}$ and $A_{\mathrm{BET}}$ were calculated from $\mathrm{N}_{2}$ adsorption/desorption data at $77 \mathrm{~K}$, while $\rho_{\mathrm{s}}$ was obtained from He pycnometry at $333 \mathrm{~K}$.

\begin{tabular}{|c|c|c|c|c|}
\hline Material & $\begin{array}{c}V_{\mathrm{p}} \\
\left(\mathrm{cm}^{3} / \mathrm{g}\right)\end{array}$ & $\begin{array}{c}A_{\mathrm{BET}} \\
\left(\mathrm{m}^{2} / \mathrm{g}\right)\end{array}$ & $\begin{array}{c}\rho_{\mathrm{s}} \\
\left(\mathrm{g} / \mathrm{cm}^{3}\right)\end{array}$ & $\begin{array}{l}\text { IL Loading } \\
\text { (wt. } \% \text { ) }\end{array}$ \\
\hline ZIF-8 & 0.665 & 1862 & 1.49 & 0.0 \\
\hline$\left[\mathrm{C}_{6} \mathrm{MIM}\right]\left[\mathrm{B}(\mathrm{CN})_{4}\right] @ \mathrm{ZIF}-8$ (low) & 0.008 & 7 & & \\
\hline$\left[\mathrm{C}_{6} \mathrm{MIM}\right]\left[\mathrm{B}(\mathrm{CN})_{4}\right] @ Z \mathrm{ZIF}-8$ reproducibility assay & 0.020 & 36 & 1.31 & 11.3 \\
\hline$\left[\mathrm{C}_{6} \mathrm{MIM}\right]\left[\mathrm{BF}_{4}\right] @ \mathrm{ZIF}-8(\mathrm{low})$ & 0.484 & 1276 & n.d. & 10.3 \\
\hline$\left[\mathrm{C}_{6} \mathrm{MIM}\right]\left[\mathrm{B}(\mathrm{CN})_{4}\right] @ \mathrm{ZIF}-8$ (low) -2 & 0.005 & 5 & 1.27 & 11.3 \\
\hline$\left[\mathrm{C}_{2} \mathrm{MIM}\right]\left[\mathrm{B}(\mathrm{CN})_{4}\right] @ Z \mathrm{ZIF}-8$ (low) & 0.028 & 48 & 1.31 & 9.3 \\
\hline$\left[\mathrm{C}_{6} \mathrm{MIM}\right]\left[\mathrm{B}(\mathrm{CN})_{4}\right] @ Z I F-8$ (high) & 0.003 & 2 & 1.28 & 23.6 \\
\hline MIL-53(Al) & 0.354 & 423 & n.d. & 0.0 \\
\hline$\left[\mathrm{C}_{6} \mathrm{MIM}\right]\left[\mathrm{B}(\mathrm{CN})_{4}\right] @ \mathrm{MIL}-53(\mathrm{Al})$ (low) & 0.229 & 167 & n.d. & 11.3 \\
\hline
\end{tabular}

A second batch of the case-study composite was produced for reproducibility check and named as $\left[\mathrm{C}_{6} \mathrm{MIM}\right]\left[\mathrm{B}(\mathrm{CN})_{4}\right] @ Z \mathrm{IF}-8$ (low) - 2. Concerning $\mathrm{N}_{2}$ adsorption/desorption at $77 \mathrm{~K}$, as shown in Figure 4 and Table 1, it also presented a Type II isotherm and similar textural properties to the first batch. Additional composites $\left[\mathrm{C}_{2} \mathrm{MIM}\right]\left[\mathrm{B}(\mathrm{CN})_{4}\right] @ \mathrm{ZIF}-8$ (low) and $\left[\mathrm{C}_{6} \mathrm{MIM}\right]\left[\mathrm{B}(\mathrm{CN})_{4}\right] @ Z I F-8$ (high) were produced to study the cation and loading effects, respectively. As observed in Figure 4 and Table 1, these two materials also showed Type II isotherms and very low textural properties.

The textural characterization of MOFs that can show some flexibility, breathing, or gating effects should be taken with care regarding the analysis of their $\mathrm{N}_{2}$ adsorption/desorption isotherms at $77 \mathrm{~K}$. Studies on MOFs like zeolitic imidazolate frameworks (ZIFs) emphasize that ZIF-8 exhibits a "swing effect", i.e., some flexibility of its framework in the form of a torsional motion of its imidazolate linkers [29]. Molecules larger than the ZIF-8 geometric window size $(\sim 3.4 \AA)$ can diffuse through the ZIF- 8 framework, a fact that is attributed to the flexibility of the structure. Moreover, ZIF- 8 has large cavities intercon- 
nected by narrow windows ( $11.6 \AA$ of diameter) [30]. These material structural effects and their phase transition between metastable phases can modify the diffusivity of gases through the porous network, and to some extent can influence the $\mathrm{N}_{2}$ adsorption isotherm (at $77 \mathrm{~K}$ ) and consequently the BET surface area and pore size distribution calculations. Nonetheless, these effects are not seen in the results obtained for pristine ZIF-8. In fact, the interaction of the IL basic anion $\left[\mathrm{B}(\mathrm{CN})_{4}\right]^{-}$with the imidazolate linker of $\mathrm{ZIF}-8$ seems to tune the material flexibility effect and directly affect the $\mathrm{N}_{2}$ diffusivity through the porous network, which reveals having an impact on the performance of ZIF-8 upon $\mathrm{N}_{2}$ adsorption at $77 \mathrm{~K}$. It is reported that regarding $\mathrm{CO}_{2},\left[\mathrm{~B}(\mathrm{CN})_{4}\right]^{-}$-based ILs display an enhanced ability to dissolve $\mathrm{CO}_{2}$ which can be based on weak cation-anion interactions of the ionic liquid $[15,16]$. However, a deeper understanding of the $\mathrm{CO}_{2}$ solvation in $\left[\mathrm{B}(\mathrm{CN})_{4}\right]^{-}$based ILs is required, as this could open an explanation for the uptake behavior on their derived MOF composites and the textural properties of those materials.

To see whether this phenomenon happens in another MOF, the IL $\left[\mathrm{C}_{6} \mathrm{MIM}\right]\left[\mathrm{B}(\mathrm{CN})_{4}\right]$ was impregnated into commercial MIL-53(Al). As shown in Figure 5, the composite has a similar isotherm shape but lower $\mathrm{N}_{2}$ uptake at $77 \mathrm{~K}$ when compared with the pristine MIL53(Al). This meant total pore volume and BET specific surface areas losses of $35 \%$ and $61 \%$, respectively. These textural property losses are similar to those obtained in our previous study [13], which considered cations and anions of different nature and size. The composite $\left[\mathrm{C}_{6} \mathrm{MIM}\right]\left[\mathrm{B}(\mathrm{CN})_{4}\right] @ \mathrm{MIL}-53(\mathrm{Al})$ (low) showed significant textural properties as a potential adsorbent, by contrast with $\left[\mathrm{C}_{6} \mathrm{MIM}\right]\left[\mathrm{B}(\mathrm{CN})_{4}\right] @ \mathrm{ZIF}-8$ (low). Therefore the behavior of $\left[\mathrm{C}_{\mathrm{n}} \mathrm{MIM}\right]\left[\mathrm{B}(\mathrm{CN})_{4}\right] @ \mathrm{ZIF}-8$ composites upon $\mathrm{N}_{2}$ adsorption at $77 \mathrm{~K}$ and respective textural properties are exclusive of this system, explained by specific $\left[\mathrm{C}_{6} \mathrm{MIM}\right]\left[\mathrm{B}(\mathrm{CN})_{4}\right]$ interactions with ZIF-8 after impregnation.



Figure 5. $\mathrm{N}_{2}$ adsorption/desorption equilibrium isotherms at $77 \mathrm{~K}$ of MIL-53(Al) and $\left[\mathrm{C}_{6} \mathrm{MIM}\right]\left[\mathrm{B}(\mathrm{CN})_{4}\right] @ \mathrm{MIL}-53(\mathrm{Al})$ (low). Closed and open symbols denote the adsorption and desorption data, respectively.

\subsection{Gas Adsorption/Desorption Equilibrium Measurements}

Solely considering the $\mathrm{N}_{2}$ adsorption/desorption data at $77 \mathrm{~K}$, the produced [ $\mathrm{C}_{\mathrm{n}} \mathrm{MIM}$ ] $\left[\mathrm{B}(\mathrm{CN})_{4}\right] @ Z \mathrm{ZIF}-8$ composites would never be considered as potential adsorbents for gas sorption applications as they show very low textural properties. However, previous 
literature $[15,16]$ indicated that $\left[\mathrm{C}_{n} \mathrm{MIM}\right]\left[\mathrm{B}(\mathrm{CN})_{4}\right]$ ILs should show affinity towards $\mathrm{CO}_{2}$. Figure 6 shows Type $\mathrm{I} \mathrm{CO}_{2}$ adsorption/desorption isotherms at $303 \mathrm{~K}$ for the pristine ZIF-8 and the produced $\left[\mathrm{C}_{n} \mathrm{MIM}\right]\left[\mathrm{B}(\mathrm{CN})_{4}\right] @ Z \mathrm{IF}-8$ materials. The composites showed inferior but significant $\mathrm{CO}_{2}$ uptake compared to ZIF-8 due to the IL pore occupation/blockage. Type I isotherms were not expected of these materials, considering the $\mathrm{N}_{2}$ at $77 \mathrm{~K}$ data. The collected gas adsorption/desorption for all materials herein can be found in Tables S1-S4 of the Supporting Information.

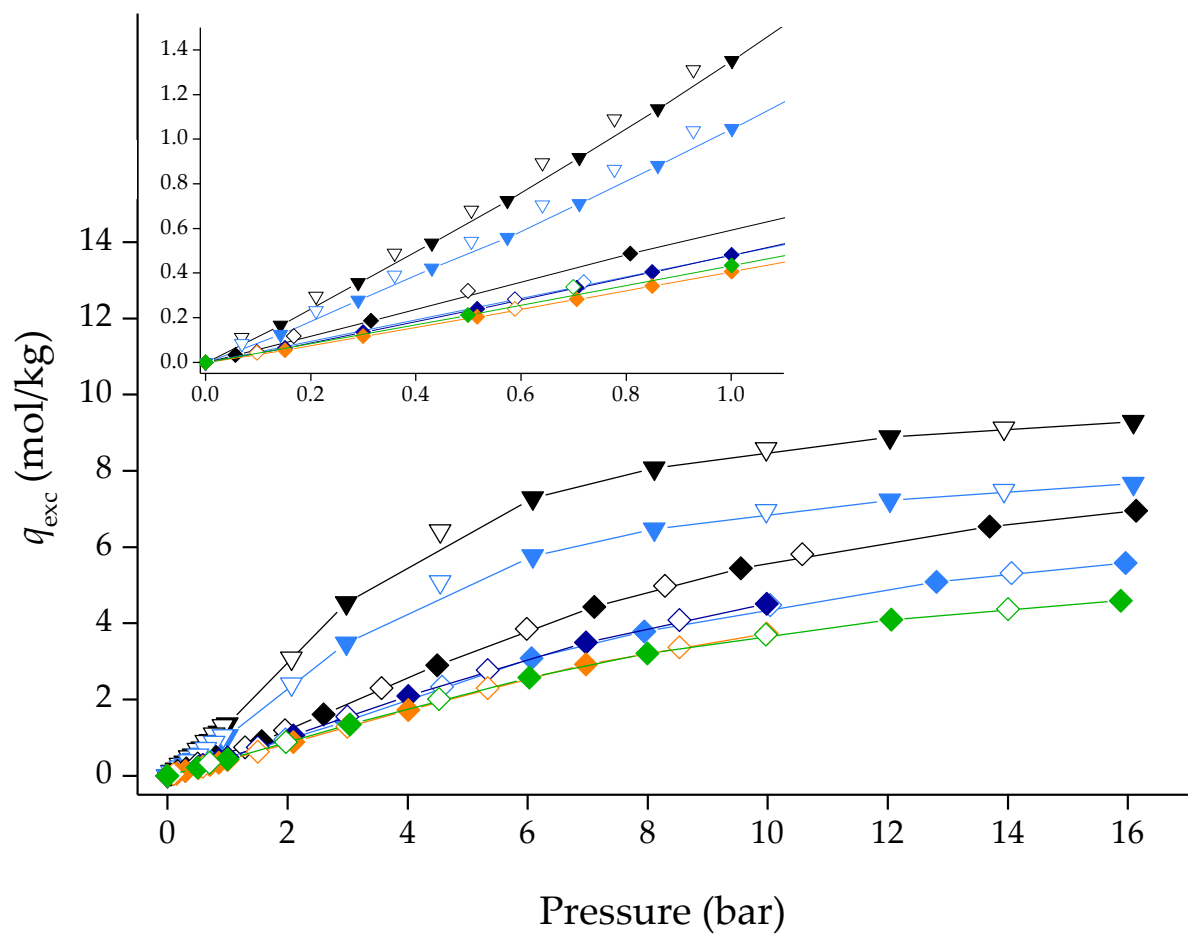

Figure 6. $\mathrm{CO}_{2}$ adsorption/desorption equilibrium isotherms at $273 \mathrm{~K}$ (inverted triangles) and $303 \mathrm{~K}$ (diamonds) for ZIF-8 and $\left[\mathrm{C}_{\mathrm{n}} \mathrm{MIM}\right]\left[\mathrm{B}(\mathrm{CN})_{4}\right] @ \mathrm{ZIF}-8$ composites. Inset for the low-pressure region is highlighted. Closed and open symbols denote the adsorption and desorption data, respectively. Lines are guides to the eye. Symbols: $\mathbf{\nabla} / \nabla \mathrm{ZIF}-8 \_273 \mathrm{~K} ; \boldsymbol{\nabla} / \nabla\left[\mathrm{C}_{6} \mathrm{MIM}\right]\left[\mathrm{B}(\mathrm{CN})_{4}\right] @ \mathrm{ZIF}-8$ (low)_273 K; $\bullet / \diamond$ ZIF-8_303 K; $\diamond / \diamond\left[\mathrm{C}_{6} \mathrm{MIM}\right]\left[\mathrm{B}(\mathrm{CN})_{4}\right] @ Z \mathrm{ZIF}-8$ (low)_303 K; $\diamond / \diamond\left[\mathrm{C}_{6} \mathrm{MIM}\right]\left[\mathrm{B}(\mathrm{CN})_{4}\right] @ Z I F-8$ (low)2_303 K; $/ \diamond\left[\mathrm{C}_{2} \mathrm{MIM}\right]\left[\mathrm{B}(\mathrm{CN})_{4}\right] @ Z \mathrm{ZIF}-8$ (low)_303 K; $\diamond / \diamond\left[\mathrm{C}_{6} \mathrm{MIM}\right]\left[\mathrm{B}(\mathrm{CN})_{4}\right] @ Z I F-8$ (high)_303 K.

The composites produced herein also adsorb in the same order of magnitude as the ones in our previous work [13], which also showed that for $\left[\mathrm{C}_{n} \mathrm{MIM}\right]\left[\mathrm{NTf}_{2}\right] @ Z \mathrm{ZIF}-8$, the shorter the side-alkyl chain, the more the composite would adsorb. Interestingly, for $\left[\mathrm{C}_{\mathrm{n}} \mathrm{MIM}\right]\left[\left[\mathrm{B}(\mathrm{CN})_{4}\right] @ Z \mathrm{IF}-8\right.$ composites, the reverse tendency is herein observed. Desorption data indicate that the materials show reversibility, as the desorption branch overlaps the adsorption one (no exhibited hysteresis).

Figure 6 also shows the $\mathrm{CO}_{2}$ adsorption/desorption equilibrium isotherms of pristine ZIF-8 and $\left[\mathrm{C}_{6} \mathrm{MIM}\right]\left[\mathrm{B}(\mathrm{CN})_{4}\right] @ Z I F-8$ (low) at $273 \mathrm{~K}$. By applying the Dubinin-Radushkevich equation to the adsorption/desorption data between $0-1$ bar $[20,21]$, it was possible to calculate the ultramicropore volume $\left(V_{\mathrm{o}}\right)$ of the two materials. The calculated ultramicropore volume of pristine ZIF-8 and $\left[\mathrm{C}_{6} \mathrm{MIM}\right]\left[\mathrm{B}(\mathrm{CN})_{4}\right] @ Z \mathrm{IF}-8$ (low) was 0.283 and $0.227 \mathrm{~cm}^{3} / \mathrm{g}$, respectively. Clearly, and in contrast with the results from $\mathrm{N}_{2}$ adsorption at $77 \mathrm{~K}, \mathrm{CO}_{2}$ data at $273 \mathrm{~K}$ indicates that $\left[\mathrm{C}_{6} \mathrm{MIM}\right]\left[\mathrm{B}(\mathrm{CN})_{4}\right] @ Z I F-8$ (low) has a microporous nature and, consequently, more significant textural properties than previously determined.

Given that $\left[\mathrm{C}_{6} \mathrm{MIM}\right]\left[\mathrm{B}(\mathrm{CN})_{4}\right] @ Z I F-8$ (low) has Type I isotherms for $\mathrm{CO}_{2}$, adsorption/desorption, isotherms of $\mathrm{CH}_{4}$ and $\mathrm{N}_{2}$ were also measured at $303 \mathrm{~K}$ for this material and the pristine ZIF-8. As shown in Figure 7, the composite material showed Type I isotherms and gas uptake in the same order of magnitude as those found for ZIF-8. This 
was notably unexpected for $\mathrm{N}_{2}$; considering that adsorption is favored by low temperatures, $\left[\mathrm{C}_{6} \mathrm{MIM}\right]\left[\mathrm{B}(\mathrm{CN})_{4}\right] @ \mathrm{ZIF}-8$ (low) should not adsorb this gas at $303 \mathrm{~K}$.

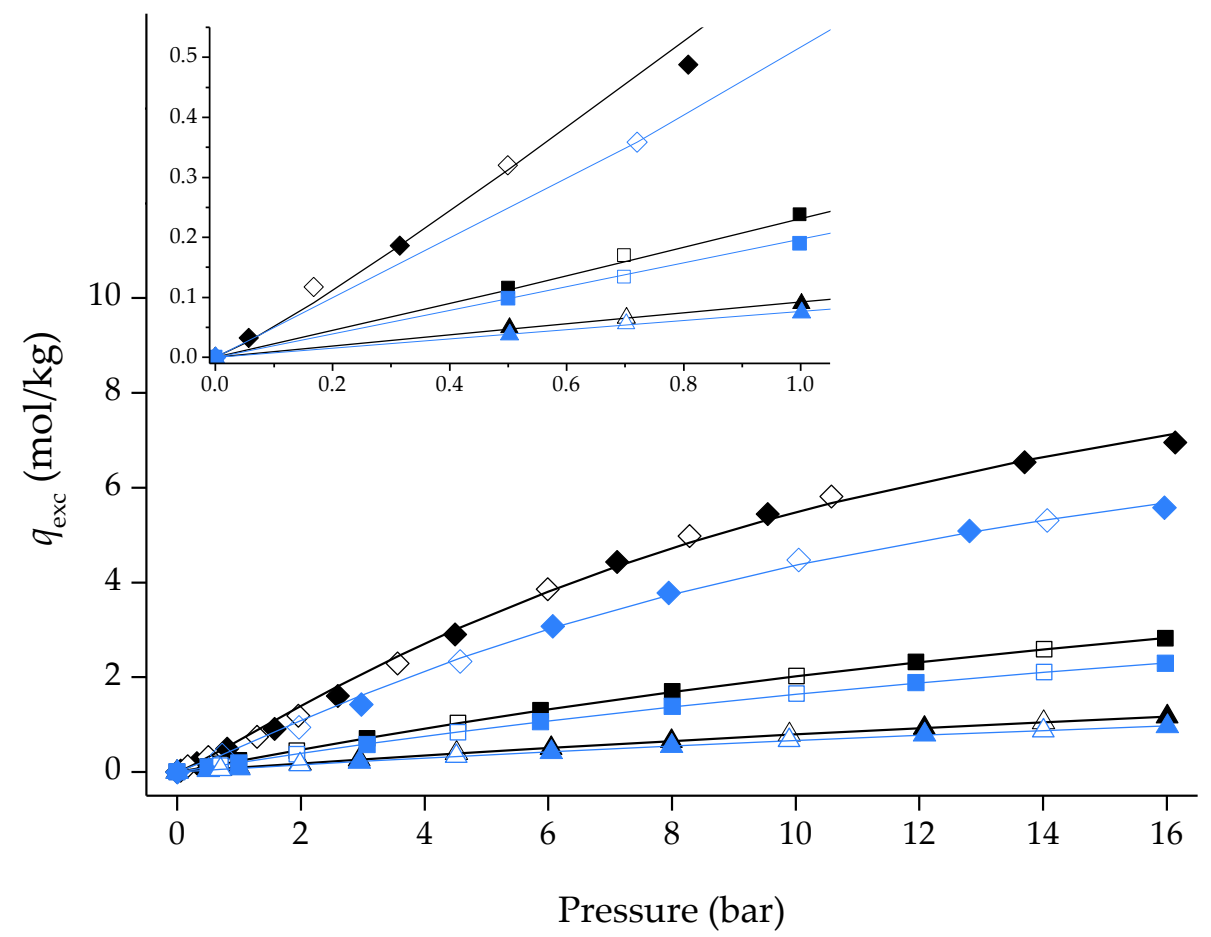

Figure 7. $\mathrm{CO}_{2}, \mathrm{CH}_{4}$ and $\mathrm{N}_{2}$ adsorption/desorption equilibrium isotherms at $303 \mathrm{~K}$ for $\mathrm{ZIF}-8$ and $\left[\mathrm{C}_{6} \mathrm{MIM}\right]\left[\mathrm{B}(\mathrm{CN})_{4}\right] @ Z I F-8$ (low) composite (with an inset for the low-pressure region). Closed and open symbols denote the adsorption and desorption data, respectively. Lines represent the Sips adsorption isotherm model fitting [18] to the experimental points. Symbols: $\bullet / \diamond \mathrm{ZIF}-8 \mathrm{CO}_{2} ; \diamond / \diamond$ $\left[\mathrm{C}_{6} \mathrm{MIM}\right]\left[\mathrm{B}(\mathrm{CN})_{4}\right] @ \mathrm{ZIF}-8$ (low)_CO $\mathrm{CO}_{2} ; \mathbf{\square} / \square \mathrm{ZIF}-8 \_\mathrm{CH}_{4} ; \mathbf{\square} / \square\left[\mathrm{C}_{6} \mathrm{MIM}\right]\left[\mathrm{B}(\mathrm{CN})_{4}\right] @ Z \mathrm{ZIF}-8$ (low)_CH CH $_{4}$ $\Delta / \triangle$ ZIF-8_N ${ }_{2} ; \Delta / \triangle\left[\mathrm{C}_{6} \mathrm{MIM}\right]\left[\mathrm{B}(\mathrm{CN})_{4}\right] @ Z \mathrm{IF}-8$ (low)_N $\mathrm{N}_{2}$.

A reasonable explanation for the $\mathrm{N}_{2}$ adsorption/desorption data at $77 \mathrm{~K}$ could be that the IL is significantly outside the pores and completely blocks the gas from entering the porous volume of the MOF, though this is not verified in the SEM micrographs presented in Figure 3. An IL-free basis was considered for $\left[\mathrm{C}_{6} \mathrm{MIM}\right]\left[\left[\mathrm{B}(\mathrm{CN})_{4}\right] @ \mathrm{ZIF}-8\right.$ (low) adsorption/desorption data at $303 \mathrm{~K}$ by normalizing the adsorbed quantity per unit mass of ZIF-8. In an IL-free basis, the composite isotherms should overlap the pristine ZIF-8 ones unless the IL affects the gas uptake (i.e., change the sorption site's nature). This is not verified, as shown in Figure 8, which indicates the IL influences the adsorption capacity of the composite material. By contrast, in our previous study [13], the IL $\left[\mathrm{P}_{66614}\right]\left[\mathrm{NTf}_{2}\right]$ was used to incorporate ZIF-8 with the same molar loading used herein. In an IL-free structure, the produced composite overlapped the ZIF-8 isotherms. According to molecular simulations studies [31], this IL essentially cannot enter the ZIF-8 porous structure. This means that only ILs found mostly outside the MOF structure will have IL-free isotherms like the original MOF. Considering this relationship, $\left[\mathrm{C}_{6} \mathrm{MIM}\right]\left[\mathrm{B}(\mathrm{CN})_{4}\right]$ is inside the ZIF-8 structure, which agrees with the SEM micrographs previously shown. 




Figure 8. Single-component adsorption/desorption equilibrium isotherms of $\mathrm{CO}_{2}, \mathrm{CH}_{4}$, and $\mathrm{N}_{2}$ on an IL-free basis in pristine ZIF-8 and $\left[\mathrm{C}_{6} \mathrm{MIM}\right]\left[\mathrm{B}(\mathrm{CN})_{4}\right] @$ ZIF-8 (low) at $303 \mathrm{~K}$. Symbols denote both adsorption and desorption data. Lines represent the Sips adsorption isotherm model fitting the experimental non-IL-free data points. Symbols: $\diamond \mathrm{ZIF-8} \mathrm{CO}_{2} ; \diamond\left[\mathrm{C}_{6} \mathrm{MIM}\right]\left[\mathrm{B}(\mathrm{CN})_{4}\right] @ \mathrm{ZIF}-8(\mathrm{low})_{-} \mathrm{CO}_{2}$;

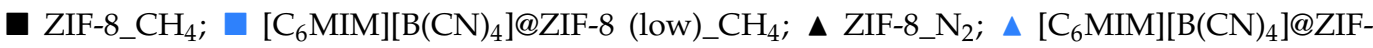
8 (low)_N $\mathrm{N}_{2}$.

Ideal $\mathrm{CO}_{2} / \mathrm{CH}_{4}$ and $\mathrm{CO}_{2} / \mathrm{N}_{2}$ selectivities were determined for both pristine $\mathrm{ZIF}-8$ and $\left[\mathrm{C}_{6} \mathrm{MIM}\right]\left[\mathrm{B}(\mathrm{CN})_{4}\right] @ Z I F-8$ (low). Table 2 shows the obtained parameters and the average relative error (ARE) of the Sips global fitting. The $q_{\mathrm{s}}$ values for both materials follow the order of less adsorbed gas to most adsorbed $\left(\mathrm{N}_{2}<\mathrm{CH}_{4}<\mathrm{CO}_{2}\right)$. Due to its higher gas uptakes, ZIF-8 shows higher $q_{\mathrm{s}}$ values than its derived composite. Parameter $b$ is also in the expected order for both materials. Gases with higher affinity for the adsorbent are more adsorbed, so the affinity parameter should, and in this case does follow the least to most adsorbed gas order. Finally, the values of parameter $n$ are near or slightly below 1 , which indicates homogeneous adsorbent-adsorbate systems.

Table 2. Sips model fitting parameters for $\mathrm{N}_{2}, \mathrm{CH}_{4}$, and $\mathrm{CO}_{2}$ on ZIF-8 and $\left[\mathrm{C}_{6} \mathrm{MIM}\right]\left[\mathrm{B}(\mathrm{CN})_{4}\right] @ Z \mathrm{ZIF}-$ 8 (low).

\begin{tabular}{|c|c|c|c|}
\hline Parameter-ZIF-8 & $\mathbf{N}_{2}$ & $\mathrm{CH}_{4}$ & $\mathrm{CO}_{2}$ \\
\hline$q_{\mathrm{s}}$ & 5.674 & 7.392 & 12.167 \\
\hline$b$ & 0.016 & 0.040 & 0.084 \\
\hline$n$ & 1.008 & 0.938 & 0.872 \\
\hline $\operatorname{ARE}(\%)$ & 1.1 & 1.3 & 7.4 \\
\hline Parameter- $\left[\mathrm{C}_{6} \mathrm{MIM}\right]\left[\mathrm{B}(\mathrm{CN})_{4}\right] @ \mathrm{ZIF}-8$ (low) & $\mathbf{N}_{2}$ & $\mathrm{CH}_{4}$ & $\mathrm{CO}_{2}$ \\
\hline$q_{\mathrm{s}}$ & 3.857 & 6.550 & 9.727 \\
\hline$b$ & 0.021 & 0.035 & 0.084 \\
\hline$n$ & 0.989 & 0.970 & 0.862 \\
\hline ARE $(\%)$ & 1.6 & 1.2 & 3.2 \\
\hline
\end{tabular}

The obtained ideal selectivities for ZIF-8 and $\left[\mathrm{C}_{6} \mathrm{MIM}\right]\left[\mathrm{B}(\mathrm{CN})_{4}\right] @ \mathrm{ZIF}-8$ (low) are shown in Figure 9. The composite shows inferior selectivity performance than the pristine ZIF-8, 
for all types of gaseous mixtures and compositions, in the entire pressure range. In our previous study [13], practically all the produced IL@ZIF-8 composites developed with the same IL molar loading as $\left[\mathrm{C}_{6} \mathrm{MIM}\right]\left[\mathrm{B}(\mathrm{CN})_{4}\right] @ \mathrm{ZIF}-8$ (low) were more selective than ZIF-8, between $0-1$ bar (i.e., adsorbent-adsorbate interactions prevail over the available pore volume in this pressure range). It is not possible to directly compare selectivities between composites, as the adsorption quantity used in that study $\left(q_{\mathrm{t}}\right)$ is different from the ones used herein $\left(q_{\text {exc }}\right)$.


$\rightarrow$ ZIF-8 $\quad \cdot\left[\mathrm{C}_{6} \mathrm{MIM}\right]\left[\mathrm{B}(\mathrm{CN})_{4}\right] @ \mathrm{ZIF}-8$ (low)

Figure 9. Ideal $\mathrm{CO}_{2} / \mathrm{CH}_{4}$ and $\mathrm{CO}_{2} / \mathrm{N}_{2}$ selectivities for the pristine $\mathrm{ZIF}-8$ and $\left[\mathrm{C}_{6} \mathrm{MIM}\right]\left[\mathrm{B}(\mathrm{CN})_{4}\right] @ \mathrm{ZIF}$ 8 (low) as a function of total pressure, determined from the Sips isotherm model fitting of the single-component adsorption/desorption isotherms, measured at $303 \mathrm{~K}$ and in the pressure range of $0.5-16$ bar.

Nevertheless, it is possible to compare the $\mathrm{CO}_{2}$ and $\mathrm{CH}_{4}$ adsorption/desorption equilibrium isotherms in excess quantities, $q_{\text {exc }}$. As observed in Figures 10 and 11, [C 6 MIM] $\left[\mathrm{B}(\mathrm{CN})_{4}\right] @ \mathrm{ZIF}-8$ (low) is the second-best composite in terms of gas adsorption capacity, only falling behind $\left[\mathrm{C}_{2} \mathrm{MIM}\right][\mathrm{Ac}] @ \mathrm{ZIF}-8$, a composite containing a chemisorption-character IL. The $\mathrm{CO}_{2}$ affinity of the $\left[\mathrm{C}_{6} \mathrm{MIM}\right]\left[\mathrm{B}(\mathrm{CN})_{4}\right]$ IL is particularly notorious at high pressure, given that its respective composite almost matches $\left[\mathrm{C}_{2} \mathrm{MIM}\right][\mathrm{Ac}] @ Z I F-8$. Surprisingly, $\left[\mathrm{C}_{6} \mathrm{MIM}\right]\left[\mathrm{B}(\mathrm{CN})_{4}\right] @ \mathrm{ZIF}-8$ (low) also shows a strong affinity towards $\mathrm{CH}_{4}$ in the entire pressure range. Considering this result and the fact that the calculated ideal selectivities of this composite were inferior to the pristine ZIF-8, it can be assumed that the $\left[\mathrm{C}_{6} \mathrm{MIM}\right]\left[\mathrm{B}(\mathrm{CN})_{4}\right]$ IL will show higher $\mathrm{N}_{2}$ affinity when compared with the other physisorption-character ILs. 


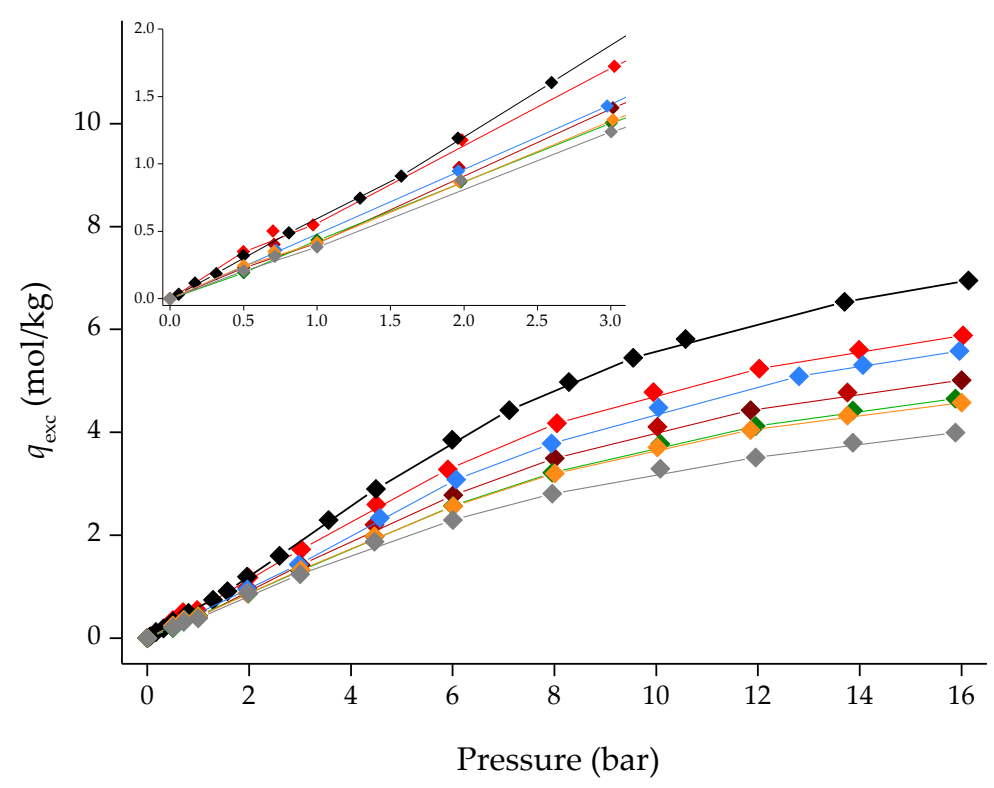

Figure 10. $\mathrm{CO}_{2}$ adsorption/desorption equilibrium isotherms for ZIF-8 and different IL@ZIF-8 composites containing the same IL molar loading at $303 \mathrm{~K}$. Symbols denote both adsorption and desorption data, respectively. Lines are guides to the eye. Symbols: $\bullet$ ZIF-8; [C 6 MIM][B(CN) ${ }_{4} @ Z$ ZIF-8 (low); $\diamond\left[\mathrm{C}_{2} \mathrm{MIM}\right][\mathrm{Ac}] @ Z I F-8([13]) ; \diamond\left[\mathrm{C}_{6} \mathrm{MIM}\right]\left[\mathrm{B}(\mathrm{CN})_{4}\right] @ Z I F-8$ (low); $\diamond\left[\mathrm{C}_{6} \mathrm{MIM}\right][\mathrm{Cl}] @ Z I F-8$ ([13]); $\diamond\left[\mathrm{C}_{6} \mathrm{MIM}\right]\left[\mathrm{C}(\mathrm{CN})_{3}\right] @ \mathrm{ZIF}-8([13]) ; \diamond\left[\mathrm{C}_{6} \mathrm{MIM}\right]\left[\mathrm{N}(\mathrm{CN})_{2}\right] @ \mathrm{ZIF}-8([13])$ and $\diamond\left[\mathrm{C}_{6} \mathrm{MIM}\right]\left[\mathrm{NTf}{ }_{2}\right] @ Z I F-$ $8([13])$.

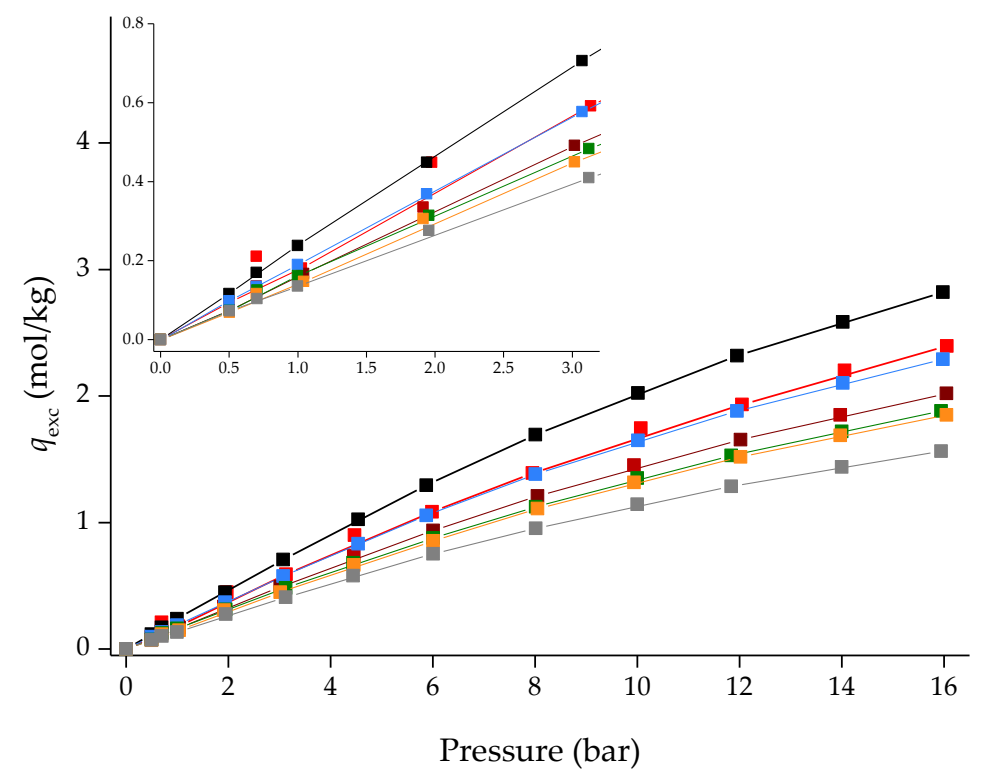

Figure 11. $\mathrm{CH}_{4}$ adsorption/desorption equilibrium isotherms for ZIF-8 and different IL@ZIF-8 composites containing the same IL molar loading at $303 \mathrm{~K}$. Symbols denote both adsorption and desorption data, respectively. Lines are guides to the eye.Symbols: $\mathbf{Z I F - 8} ;\left[\mathrm{C}_{6} \mathrm{MIM}\right]\left[\mathrm{B}(\mathrm{CN})_{4}\right] @ \mathrm{ZIF}-$

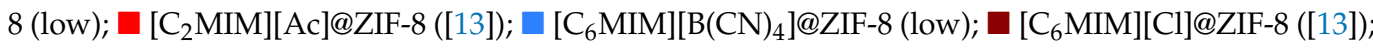

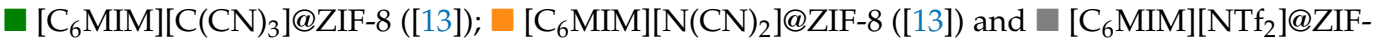
8 ([13]).

\section{Conclusions}

In this work, different $\left[\mathrm{C}_{n} \mathrm{MIM}\right]\left[\left[\mathrm{B}(\mathrm{CN})_{4}\right] @ Z I F-8\right.$ composites were produced to determine their potential for $\mathrm{CO}_{2}$ capture/separation. Characterization techniques of the case study $\left[\mathrm{C}_{6} \mathrm{MIM}\right]\left[\mathrm{B}(\mathrm{CN})_{4}\right] @ Z I F-8$ (low) composite confirmed the incorporation of the 
IL into the structure of the MOF, and that the impregnation did not significantly alter the crystalline structure and morphology of ZIF-8. Unexpected results regarding the textural properties of this and other $\left[\mathrm{C}_{\mathrm{n}} \mathrm{MIM}\right]\left[\left[\mathrm{B}(\mathrm{CN})_{4}\right] @ \mathrm{ZIF}-8\right.$ composites were obtained from $\mathrm{N}_{2}$ adsorption/desorption data at $77 \mathrm{~K}$, which indicated that the materials were nonporous. However, gas adsorption isotherms measured at $303 \mathrm{~K}$ (and $273 \mathrm{~K}$ ) indicate that $\left[\mathrm{C}_{\mathrm{n}} \mathrm{MIM}\right]\left[\left[\mathrm{B}(\mathrm{CN})_{4}\right] @ \mathrm{ZIF}-8\right.$ composites are microporous, with the potential to be used as sorbents for gas separation/capture applications by adsorption. The authors would like to point out the importance of completely ascertaining the porous nature of the produced IL@MOF materials. Nonporous materials determined by $\mathrm{N}_{2}$ adsorption/desorption equilibrium at $77 \mathrm{~K}$ should not be immediately ruled as unsatisfactory materials and have their adsorption capacity/porous nature further tested with closer-to-room-temperature measurements.

Ideal selectivities were calculated for $\left[\mathrm{C}_{6} \mathrm{MIM}\right]\left[\mathrm{B}(\mathrm{CN})_{4}\right] @ \mathrm{ZIF}-8$ (low) from the obtained $\mathrm{CO}_{2}, \mathrm{CH}_{4}$, and $\mathrm{N}_{2}$ adsorption/desorption equilibrium isotherms. When compared to the pristine ZIF-8, the composite showed inferior selectivity performance. Comparisons drawn with composites produced in a previous study indicate that indeed $\left[\mathrm{C}_{6} \mathrm{MIM}\right]\left[\mathrm{B}(\mathrm{CN})_{4}\right.$ shows enhanced affinity for $\mathrm{CO}_{2}$, but also towards $\mathrm{CH}_{4}$ (and likely $\mathrm{N}_{2}$ ) when compared with other physisorption ILs. This explains the low selectivities of the $\left[\mathrm{C}_{6} \mathrm{MIM}\right]\left[\mathrm{B}(\mathrm{CN})_{4}\right] @ \mathrm{ZIF}-8$ (low) composite.

Supplementary Materials: The following are available online at https://www.mdpi.com/article/10 $.3390 /$ pr10020247/s1, Table S1: $\mathrm{CO}_{2}, \mathrm{CH}_{4}$ and $\mathrm{N}_{2}$ adsorption-desorption equilibrium data at $303 \mathrm{~K}$ for pristine ZIF-8, Table S2: $\mathrm{CO}_{2}, \mathrm{CH}_{4}$ and $\mathrm{N}_{2}$ adsorption-desorption equilibrium data at $303 \mathrm{~K}$ for $\left[\mathrm{C}_{6} \mathrm{MIM}\right]\left[\mathrm{B}(\mathrm{CN})_{4}\right] @ Z \mathrm{ZIF}-8$ (low), Table S3: $\mathrm{CO}_{2}$ adsorption-desorption equilibrium data at $303 \mathrm{~K}$ for $\left[\mathrm{C}_{\mathrm{n}} \mathrm{MIM}\right]\left[\mathrm{B}(\mathrm{CN})_{4}\right] @ \mathrm{ZIF}-8$ materials, Table S4: $\mathrm{CO}_{2}$ adsorption-desorption equilibrium data at $273 \mathrm{~K}$ for pristine ZIF-8 and $\left[\mathrm{C}_{6} \mathrm{MIM}\right]\left[\mathrm{B}(\mathrm{CN})_{4}\right] @ \mathrm{ZIF}-8$ (low).

Author Contributions: Conceptualization, I.A.A.C.E. and J.M.S.S.E.; methodology, I.A.A.C.E., J.M.S.S.E., T.J.F. and L.M.E.; validation, T.J.F. and L.M.E.; formal analysis, T.J.F., L.M.E., I.A.A.C.E. and J.M.S.S.E.; investigation, T.J.F. and L.M.E.; writing—original draft preparation, T.J.F.; writing—review and editing, I.A.A.C.E., J.M.S.S.E., T.J.F. and L.M.E.; supervision, I.A.A.C.E. and J.M.S.S.E.; funding acquisition, I.A.A.C.E. and J.M.S.S.E. All authors have read and agreed to the published version of the manuscript.

Funding: The authors acknowledge "Fundação para a Ciência e Tecnologia" through the PhD grant SFRH/BD/139627/2018 (T. J. Ferreira). This work was also supported by the Associate Laboratory for Green Chemistry-LAQV (Portugal), which is financed by national funds from FCT/MCTES (UIDB/50006/2020, UIDP/50006/2020, and LA/P/0008/2020), and projects PTDC/CTM-CTM/ $30326 / 2017$ and IF/01016/2014.

Institutional Review Board Statement: Not applicable.

Informed Consent Statement: Not applicable.

Data Availability Statement: Data is contained in the article and respective Supporting Information.

Conflicts of Interest: The authors declare no conflict of interest.

\section{References}

1. Solomon, S.; Plattner, G.-K.; Knutti, R.; Friedlingstein, P. Irreversible climate change due to carbon dioxide emissions. Proc. Natl. Acad. Sci. USA 2009, 106, 1704-1709. [CrossRef] [PubMed]

2. IPCC. Climate Change 2013: The Physical Science Basis. Contribution of Working Group I to the Fifth Assessment Report of the Intergovernmental Panel on Climate Change; IPCC: Cambridge, UK, 2013.

3. Sifat, N.S.; Haseli, Y. A critical review of $\mathrm{CO}_{2}$ capture technologies and prospects for clean power generation. Energies 2019, 12, 4143. [CrossRef]

4. Budinis, S.; Krevor, S.; Dowell, N.M.; Brandon, N.; Hawkes, A. An assessment of CCS costs, barriers and potential. Energy Strateg. Rev. 2018, 22, 61-81. [CrossRef]

5. Aghaie, M.; Rezaei, N.; Zendehboudi, S. A systematic review on $\mathrm{CO}_{2}$ capture with ionic liquids: Current status and future prospects. Renew. Sustain. Energy Rev. 2018, 96, 502-525. [CrossRef]

6. Aniruddha, R.; Sreedhar, I.; Reddy, B.M. MOFs in carbon capture-past, present and future. J. CO2 Util. 2020, 42, 101297. [CrossRef] 
7. Ozdemir, J.; Mosleh, I.; Abolhassani, M.; Greenlee, L.F.; Beitle, R.R., Jr.; Beyzavi, M.H. Covalent Organic Frameworks for the Capture, Fixation, or Reduction of $\mathrm{CO}_{2}$. Front. Energy Res. 2019, 7, 77. [CrossRef]

8. Mukherjee, S.; Sikdar, N.; O’Nolan, D.; Franz, D.M.; Gascón, V.; Kumar, A.; Kumar, N.; Scott, H.S.; Madden, D.G.; Kruger, P.E.; et al. Trace $\mathrm{CO}_{2}$ capture by an ultramicroporous physisorbent with low water affinity. Sci. Adv. 2019, 5, eaax9171. [CrossRef]

9. Ahmed, I.; Jhung, S.H. Composites of metal-organic frameworks: Preparation and application in adsorption. Mater. Today 2014, 17, 136-146. [CrossRef]

10. Cota, I.; Fernandez Martinez, F. Recent advances in the synthesis and applications of metal organic frameworks doped with ionic liquids for $\mathrm{CO}_{2}$ adsorption. Coord. Chem. Rev. 2017, 351, 189-204. [CrossRef]

11. Zeeshan, M.; Nozari, V.; Yagci, M.B.; Isık, T.; Unal, U.; Ortalan, V.; Keskin, S.; Uzun, A. Core-Shell Type Ionic Liquid/Metal Organic Framework Composite: An Exceptionally High $\mathrm{CO}_{2} / \mathrm{CH}_{4}$ Selectivity. J. Am. Chem. Soc. 2018, 140, 10113-10116. [CrossRef]

12. Mohamedali, M.; Ibrahim, H.; Henni, A. Incorporation of acetate-based ionic liquids into a zeolitic imidazolate framework (ZIF-8) as efficient sorbents for carbon dioxide capture. Chem. Eng. J. 2018, 334, 817-828. [CrossRef]

13. Ferreira, T.J.; Ribeiro, R.P.P.L.; Mota, J.P.B.; Rebelo, L.P.N.; Esperança, J.M.S.S.; Esteves, I.A.A.C. Ionic Liquid-Impregnated Metal-Organic Frameworks for $\mathrm{CO}_{2} / \mathrm{CH}_{4}$ Separation. ACS Appl. Nano Mater. 2019, 2, 7933-7950. [CrossRef]

14. Amiri, N.; Benyounes, H.; Lounis, Z.; Shen, W. Design of absorption process for $\mathrm{CO}_{2}$ capture using cyano based anion ionic liquid. Chem. Eng. Res. Des. 2021, 169, 239-249. [CrossRef]

15. Carvalho, P.J.; Kurnia, K.A.; Coutinho, J.A.P. Dispelling some myths about the $\mathrm{CO}_{2}$ solubility in ionic liquids. Phys. Chem. Chem. Phys. 2016, 18, 14757-14771. [CrossRef]

16. Zakrzewska, M.E.; Nunes da Ponte, M. Volumetric and phase behaviour of mixtures of tetracyanoborate-based ionic liquids with high pressure carbon dioxide. J. Supercrit. Fluids 2016, 113, 31-38. [CrossRef]

17. Hasib-ur-Rahman, M.; Siaj, M.; Larachi, F. Ionic liquids for CO2 capture-Development and progress. Chem. Eng. Process. Process Intensif. 2010, 49, 313-322. [CrossRef]

18. Do, D.D. Adsorption Analysis: Equilibria and Kinetics; Imperial College Press: London, UK, 1998.

19. Thommes, M.; Kaneko, K.; Neimark, A.V.; Olivier, J.P.; Rodriguez-Reinoso, F.; Rouquerol, J.; Sing, K.S.W. Physisorption of gases, with special reference to the evaluation of surface area and pore size distribution (IUPAC Technical Report). Pure Appl. Chem. 2015, 87, 1051-1069. [CrossRef]

20. Lozano-Castelló, D.; Cazorla-Amorós, D.; Linares-Solano, A. Usefulness of $\mathrm{CO}_{2}$ adsorption at $273 \mathrm{~K}$ for the characterization of porous carbons. Carbon N. Y. 2004, 42, 1233-1242. [CrossRef]

21. Sevilla, M.; Fuertes, A.B. Sustainable porous carbons with a superior performance for $\mathrm{CO}_{2}$ capture. Energy Environ. Sci. 2011, 4, 1765-1771. [CrossRef]

22. Esteves, I.A.A.C.; Lopes, M.S.S.; Nunes, P.M.C.; Mota, J.P.B. Adsorption of natural gas and biogas components on activated carbon. Sep. Purif. Technol. 2008, 62, 281-296. [CrossRef]

23. Camacho, B.C.R.; Ribeiro, R.P.P.L.; Esteves, I.A.A.C.; Mota, J.P.B. Adsorption equilibrium of carbon dioxide and nitrogen on the MIL-53 (Al) metal organic framework. Sep. Purif. Technol. 2015, 141, 150-159. [CrossRef]

24. Ferreira, T.J.; Vera, A.T.; de Moura, B.A.; Esteves, L.M.; Tariq, M.; Esperança, J.M.S.S.; Esteves, I.A.A.C. Paramagnetic Ionic Liquid/Metal Organic Framework Composites for $\mathrm{CO}_{2} / \mathrm{CH}_{4}$ and $\mathrm{CO}_{2} / \mathrm{N}_{2}$ Separations. Front. Chem. 2020, 8, 590191. [CrossRef] [PubMed]

25. Gumma, S.; Talu, O. Net Adsorption: A Thermodynamic Framework for Supercritical Gas Adsorption and Storage in Porous Solids. Langmuir 2010, 26, 17013-17023. [CrossRef]

26. Surra, E.; Bernardo, M.; Lapa, N.; Esteves, I.A.A.C.; Fonseca, I.; Mota, J.P.B. Biomethane Production Through Anaerobic CoDigestion with Maize Cob Waste Based on a Biorefinery Concept: A Review. J. Environ. Manag. 2019, 249, 109351. [CrossRef] [PubMed]

27. Boyd, P.G.; Chidambaram, A.; García-Díez, E.; Ireland, C.P.; Daff, T.D.; Bounds, R.; Gładysiak, A.; Schouwink, P.; Moosavi, S.M.; Maroto-Valer, M.M.; et al. Data-driven design of metal-organic frameworks for wet flue gas $\mathrm{CO}_{2}$ capture. Nature 2019, 576, 253-256. [CrossRef] [PubMed]

28. Tomé, L.C.; Isik, M.; Freire, C.S.R.; Mecerreyes, D.; Marrucho, I.M. Novel pyrrolidinium-based polymeric ionic liquids with cyano counter-anions: High performance membrane materials for post-combustion $\mathrm{CO}_{2}$ separation. J. Memb. Sci. 2015, 483, 155-165. [CrossRef]

29. Coudert, F.X. Molecular Mechanism of Swing Effect in ZeoliticImidazolate Framework ZIF-8: C ontinuous Deformation upon Adsorption. ChemPhysChem 2017, 18, 2732-2738. [CrossRef]

30. Fairen-Jimenez, D.; Moggach, S.A.; Wharmby, M.T.; Wright, P.A.; Parsons, S.; Düren, T. Opening the Gate: Framework Flexibility in ZIF-8 Explored by Experiments and Simulations. J. Am. Chem. Soc. 2011, 133, 8900-8902. [CrossRef]

31. Costa Gomes, M.; Pison, L.; Červinka, C.; Padua, A. Porous Ionic Liquids or Liquid Metal-Organic Frameworks? Angew. Chem. 2018, 130, 12085-12088. [CrossRef] 